\title{
Sustainable intensification of agriculture is key to feeding Africa in the 21st century
}

\author{
Shenggen FAN (ه) \\ College of Economics and Management, China Agricultural University, Beijing 100083, China
}

\begin{abstract}
Africa in facing numerous challenges in the 21st century in feeding its rapidly increasing population. Land resources have become limited due to urbanization and industrialization. The existing agricultural land has been degraded and soil fertility has declined due to unsustainable farming practices. Despite of progress made in the past several decades, hunger and malnutrition in Africa still hinder health, human development and economic growth, which will become even worse in the future if proper measures are not taken. Sustainable intensification is the only solution to tackling both environmental sustainability including climate change and malnutrition, i.e., to produce more foods in terms of nutrients human body needs with less natural resources and carbon emissions. To achieve this vision, innovations in technologies, policies and institutions are essential. The Chinese experience in Agricultural Green Development (AGD) can be shared with Africans when the region is pursuing its sustainable intensification strategy.
\end{abstract}

Keywords Africa, sustainable intensification, Agricultural Green Development, climate change, malnutrition

\section{Introduction}

African countries are facing unprecedented challenges in agriculture and food systems with the triple burden of malnutrition that is causing a major health crisis. In 2017 , more than 257 million people or $20 \%$ of Africa's population are suffering from hunger or lack of adequate dietary energy. About 59 million (30.3\%) of children under five are stunted. Almost $12 \%$ of adults are obese and $5 \%$ of children under five are overweight ${ }^{[1]}$. The ongoing COVID-19 pandemic could double the number of poor and hungry people in Africa if proper measures are not taken ${ }^{[2]}$. African food and agriculture sectors are among the most vulnerable to the negative impacts of climate change. Smallholder farmers, small entrepreneurs and their families, whose livelihoods depend on rainfed agriculture, are the most threatened by climate change. Also, since 1950,65\% of African cropland, on which millions depend, has been affected by land degradation due to poor farming practices, illegal clearing and by mining ${ }^{[3]}$. Therefore, a new strategies to produce more healthy and nutritious foods using limited resources and resilient to climate change will have to be developed and implemented. The Chinese experience on Agricultural Green Development (AGD) can provide insights into how such a strategy can be developed and implemented through national policies and strategies $^{[4]}$.

\section{Africa is facing unprecedented challenges in agriculture, food and nutrition security}

African countries face numerous challenges in agriculture, food and nutrition security. Among them, low land productivity and vulnerability to climate change are particularly significant.

Food production systems in Africa have been characterized by low productivity over the last few decades. Land productivity increased from 190 to 335 USD between 1990 and 2015, i.e., 2.2\% per year (Table 1). This is lower than annual population growth of $2.5 \%$ over the same period. By comparison in Asia, land productivity grew at more than

Received May 15, 2020

Correspondence: s.fan@cau.edu.cn

(c) The Author(s) 2020. Published by Higher Education Press. This is an open access article under the CC BY license (http://creativecommons.org/licenses/by/4.0) 
Table 1 Land, labor and total factor productivity

\begin{tabular}{|c|c|c|c|c|c|c|c|c|c|c|c|}
\hline \multirow{2}{*}{ Region } & \multicolumn{4}{|c|}{ Land productivity/USD } & \multicolumn{4}{|c|}{ Labor productivity/USD } & \multicolumn{3}{|c|}{ Total factor productivity growth $/ \%$} \\
\hline & 1990 & 2000 & 2010 & 2015 & 1990 & 2000 & 2010 & 2015 & $1991-2000$ & 2001-2010 & 2011-2015 \\
\hline Sub-Saharan Africa & 190 & 239 & 319 & 335 & 1084 & 1438 & 1887 & 2078 & 1.5 & 1.0 & 0.4 \\
\hline Latin America and the Caribbean & 255 & 336 & 468 & 526 & 5710 & 7903 & 12404 & 15447 & 1.3 & 2.3 & 1.9 \\
\hline Asia and the Pacific & 646 & 909 & 1219 & 1355 & 803 & 1104 & 1738 & 2298 & 1.7 & 1.7 & 1.5 \\
\hline Middle East and North Africa & 1073 & 1344 & 1596 & 1738 & 2565 & 3491 & 4484 & 5240 & 1.3 & 1.5 & 1.2 \\
\hline
\end{tabular}

Note: Source from IFPRI 2020 Global Food Policy Report ${ }^{[5]}$.

$3 \%$ per year with a population growth of only $1.2 \%$ per year. Labor productivity in Africa grew by $2.6 \%$ per year, but in Asia the growth was over $4.2 \%$ per year. In Africa, total factor productivity (TFP), which measures the ratio of total output to total input, has grown even slower and the growth rate has declined in recent years from $1.5 \%$ per year in 1990-2000 to $1 \%$ per year in 2001-2010, and $0.5 \%$ per year in 2011-2015. In Asia, TFP grew annually by $1.7 \%$, $1.7 \%$ and $1.5 \%$ during these periods, respectively.

In absolute terms, in 2015, labor productivity in Africa was $90 \%$ of that in Asia, partly due to its more favorable land/ labor ratio, with land productivity in Africa only about a quarter of that in Asia. The lower land productivity, slower TFP growth and relatively high labor productivity growth is a strong indicator that agricultural growth in Africa was a result of land use expansion rather than land productivity growth driven by technological change.

Food security in many sub-Saharan African (SSA) countries is extremely vulnerable to the negative impacts of climate change (including higher temperatures and more variable precipitation patterns) resulting in reduced yields, farm incomes and welfare. Average crop yields are projected to decline by $8 \%$ by $2050^{[6]}$ with large regional variation. For example, without adequate adaptation measures, climate change in eastern Africa is predicted to decrease yields by $5 \%-20 \%$ for wheat, soybean, sorghum and irrigated rice, whereas rainfed maize and rainfed rice yields are projected to increase slightly ${ }^{[7]}$. The impact will also vary within countries, with certain areas becoming unsuitable for crop production (such as maize in parts of West Pokot County, Kenya), whereas other areas will improve the potential for crop production (such as irrigated maize in the Rift Valley). Similar analyses can also be found for western and southern Africa, albeit with differing subregional, country (and sub-country) and crop impacts $^{[8,9]}$.

The impacts of a changing climate on agroecosystems will challenge food production systems that are already under pressure to feed a growing populations throughout Africa. Under a climate change scenario, SSA food availability in 2050 will be about 500 calories less than the no-climate-change scenario and 400 calories less than the 2000 average ${ }^{[10]}$. Even without climate change, Africa is the only region where the number of malnourished children is projected to increase between 2000 and 2050 (from 33 million to 42 million).

\section{Sustainable intensification is the only solution to feed Africans in the future}

The population of Africa has increased rapidly. From an estimated 140 million in 1900, it had grown to around a billion in 2010. According to the United Nation's medium scenario projections, this figure will rise to 2.5 billion in 2050 and more than 4 billion in 2100. Together with projected strong economic growth and urbanization, demand for more and better food will be stronger than ever.

Past agricultural growth in Africa has been driven mainly by the expansion of the area cropped rather than productivity increases as shown in Table 1. In addition, the intensification that has taken place has resulted in widespread land degradation and soil nutrient depletion ${ }^{[11,12]}$. The potential of production growth based on land expansion will be reached quickly given continued high population growth ${ }^{[13,14]}$.

Thus, African countries must use their limited resources to produce more and better food for increasingly richer and urbanized population through a sustainable intensification strategy for agriculture. In recent years, considerable policy development and research have been directed toward sustainable agricultural intensification, which is commonly defined as a form of production in which "yields are increased without adverse environmental impact and without the cultivation of more land"[15]. Originally used in reference to low-yielding agriculture in SSA, calls for more environmentally-friendly pathways within modern high-intensity food production systems have gradually become more prominent in food and nutrition security discourse since the early 1990s amid increasing population, consumption and environmental pressure ${ }^{[16,17]}$. However, because sustainable intensification is more of an 
aspirational framework rather than an endorsement of a particular agricultural production system, vigorous debate persists regarding what it will look like on the ground ${ }^{[17]}$. In recent years, discussions around sustainable intensification have shifted emphasis away from an overwhelming production-oriented perspective toward a greater balance between sustainability and intensification, and the inclusion of both technological and socioeconomic approaches regarding food demand, nutrition, governance, food losses and waste, distribution and governance issues $^{[17-19]}$. This approach embodies the entire food system, with new tools to better understand it are still under development. Due to challenges in both health and nutrition, and natural resources and climate change, sustainable intensification is defined in this paper as producing more foods in terms of nutrients human body needs with less natural resources and carbon emissions. To achieve this vision, innovations in technologies, policies and institutions are essential.

Chinese experience is particularly relevant here. Until recently, growth in Chinese food production mainly came from the increased use of water, land, fertilizer, pesticides and other off-farm inputs. As a result, the natural resource base has been degraded. Overuse of fertilizer and pesticides and other off-farm inputs has led to environmental damage and food safety issues. It was clear that this type of intensification is not sustainable. To tackle this challenge, the Nineteenth National People's Congress introduced a national strategy for sustainable development in China-realizing green development or AGD. The overall objective of AGD is to coordinate "green" with "development" to realize the transformation of current agriculture with high resource consumption and high environmental costs into a green agriculture and rural areas with high productivity, high resource use efficiency and low environmental impact ${ }^{[4]}$. The Chinese experience in AGD can be shared with Africans when the region is pursuing its sustainable intensification strategy.

\section{Innovations in technology}

Technological innovations are key to concurrently tackling multiple challenges in Africa. Yield-enhancing and conservation technologies, such as remote sensing, precision agriculture and no-tillage, have shown some benefits for productivity and efficient use of natural resources. Technologies should focus not only on increasing yield and productivity, but also on achieving multiple benefits, including climate adaptation, greenhouse gas mitigation, and nutrition.

Climate change will lead to more droughts in Africa, new technologies leading to improved crop and animal genotypes must include drought tolerance. Some successes have already been achieved, for example drought tolerant maize released by the International Maize and Wheat Improvement Center (CIMMYT) and the International Institute for Tropical Agriculture (IITA), in close collaboration with national agricultural research systems, can increase maize yields by over $1 \mathrm{t} / \mathrm{ha}$ under moderate drought and with a $20 \%-30 \%$ increase over current yields, benefiting up to 40 million people in 13 African countries ${ }^{[20]}$.

Microdosing of fertilizer has reintroduced fertilizer use in Zimbabwe, Mozambique and South Africa in the southern Africa. In western Africa, currently, some 25000 smallholders in Burkina Faso, Mali and Niger have learned the technique and experienced increases in sorghum and millet yields of $44 \%-120 \%$, along with an increase in their family incomes of $50 \%-130 \%{ }^{[21]}$. Solar-powered irrigation pumps are one of Africa's most promising solutions to climate change adaption and mitigation and reduction in hunger and malnutrition ${ }^{[22]}$. As efforts to bring electricity to rural areas continue to stall and rainfall remains sporadic across much of the continent, these pumps to bring water to parched fields and to increase food production is gaining strong momentum. However, water rights and the right incentives must be introduced to avoid excessive extraction of underground water.

The use of crop covers increases soil fertility and yields due to biological nitrogen fixing in soils, improves water holding capacity and has great potential to soil carbon sequestration ${ }^{[23]}$.

Biofortification, the process of increasing vitamin and mineral density in crops through plant breeding, transgenic techniques and agronomic practices, improves human health and nutrition in a cost-effective way that can reach underserved, rural populations ${ }^{[24]}$. Today more than 40 million smallholder families are producing and consuming biofortified foods in developing countries.

There are also exciting new and potentially transformative technologies. Gene editing for seed improvements can produce more crops and improve nutrition outcomes; big data and analytics can lower transaction costs and mitigate risk for farmers; and blockchain can enable traceability and transparency along the food supply chain ${ }^{[25]}$. These technologies should be scaled up, but only with careful consideration of their impact in Africa on smallholders, nutrition of children and employment. 


\section{Innovations in policy and institutions}

Tailored policies and programs are needed for populations uniquely impacted by current trends in food security and nutrition, namely smallholders and the urban poor. To enhance climate adaptation in smallholder agriculture, policies can promote land rights and efficient land markets (including new arrangements in land rental markets), and improve risk-management, mitigation and adaptation strategies through insurance and information services. Social protection systems can build on successes, such as the Productive Safety Net Program in Ethiopia, to provide both safety nets and agricultural support to help secure basic livelihoods while building resilience to shocks. At the same time, measures to increase the access of the urban poor to healthy and nutritious foods and to promote healthy choices will be important.

Under rapid urbanization, institutions must encouraging inclusive value chains. Institutions can support the quiet revolution taking place in traditional value chains, as seen in the expansion and modernization of farms, mills and markets in the Asian rice value chain ${ }^{[26]}$. Institutions can also enhance vertical and horizontal coordination by promoting efficiency-building competition among different farming models such as cooperatives and family farms, and also by improving farm-to-market synchronization. Urban and rural policymakers can cooperate to support the flow of products into cities and also to fully harness the opportunities available from growing urbanization to integrate smallholders, traders, and others into the urban markets along the full food value chain.

Furthermore, institutions are crucial for climate-smart agriculture, particularly in serving as a center for information, innovation, investment and insurance. To encourage adoption of climate-smart agricultural practices, local institutions should facilitate access to many resources and to information for stakeholders. Institutions providing insurance and related information for climate-smart agriculture will need to be more inclusive in incorporating local perspectives while tailoring the products and practices for smallholders. As many climate-smart agricultural practices will need to occur at a large spatial scale and over a longer time frame, institutions will be key for coordination and continued support through social safety nets. Additionally, institutions can promote partnerships for climate-smart adaption and support various climate-friendly financial arrangements.

\section{Conclusions}

Africa has the highest rate of hunger and poverty on any continent and its population will continue to grow rapidly. Natural resources like land, water and forestry are under tremendous pressure. The continent will be hit particularly hard by climate change. Sustainable intensification is the only option to feed its population nutritiously healthily in a sustainable manner. Innovations in technologies, policies and institutions are critical. There are already promising technologies under development. Policymaking capacity and governance have also improved recently, but more needs to be done. To facilitate further innovations, public investment in agricultural R\&D, capacity strengthening of the innovation systems and policy research and policymaking, and improved central and local governance will be key. Cooperation between African and Asian countries, particularly based on AGD in China, can accelerate the development and adoption of sustainable intensification practices in Africa.

\section{References}

1. FAO, ECA. Africa Regional Overview of Food Security and Nutrition. Addressing the threat from climate variability and extremes for food security and nutrition. Accra, 2018, 1-116

2. Vos R, Martin W, Laborde D. How much will global poverty increase because of COVID-19? Released on March 20, 2020. Available at International Food Policy Research Institute (IFPRI) website on May 27, 2020

3. Yakupitiyage T. Land degradation: a triple threat in Africa. Available at Inter Press Service (IPS) website on May 27, 2020

4. Shen J B, Zhu Q C, Jiao X Q, Ying H, Wang H L, Wen X, Xu W, Li T Y, Cong W F, Liu X J, Hou Y, Cui Z, Oenema O, Davies W J, Zhang F. Agriculture Green Development: a model for China and the World. Frontiers of Agricultural Science and Engineering, 2020, 7(1): 5-13

5. FAO. Family Farming Knowledge Platform. The 2020 Global Food Policy Report. Available at FAO website on May 27, 2020

6. Knox J W, Hess T, Daccache A, Wheeler T. Climate change impacts on crop productivity in Africa and South Asia. Environmental Research Letters, 2013, 7(3): 034032

7. Waithaka M M, Nelson G C, Thomas T S, Kyotalimye M. East African agriculture and climate change: a comprehensive analysis. Washington DC, USA: International Food Policy Research Institute, 2013

8. Hachigonta S, Nelson G C, Thomas T S, Sibanda L M. Southern African agriculture and climate change: a comprehensive analysis. Washington 
DC, USA: International Food Policy Research Institute, 2013

9. Jalloh A, Nelson G C, Thomas T S, Zougmoré R B. West African agriculture and climate change: a comprehensive analysis. Washington DC, USA: International Food Policy Research Institute, 2013

10. Nelson G C, Rosegrant M W, Koo J, Robertson R, Sulser T, Zhu T, Ringler C, Msangi S, Palazzo A, Batka M, Magalhaes M, Valmonte-Santos R, Ewing M, Lee D. Climate change: impact on agriculture and costs of adaptation. Washington DC, USA: International Food Policy Research Institute, 2009

11. Drechsel P, Gyiele L, Kunze D, Cofie O. Population density, soil nutrient depletion, and economic growth in sub-Saharan Africa. Ecological Economics, 2001, 38(2): 251-258

12. Tittonell P, Giller K E. When yield gaps are poverty traps: The paradigm of ecological intensification in African smallholder agriculture. Field Crops Research, 2013, 143(1): 76-90

13. Masters W A, Djurfeldt A A, De Haan C, Hazell P, Jayne T, Jirström M, Reardon T. Urbanization and farm size in Asia and Africa: implications for food security and agricultural research. Global Food Security, 2013, 2(3): 156-165

14. Chamberlin J, Jayne T S, Headey D. Scarcity amidst abundance? Reassessing the potential for cropland expansion in Africa. Food Policy, 2014, 48: $51-65$

15. Royal Society. Reaping the benefits: science and the sustainable intensification of global agriculture. London: Royal Society, 2009

16. Tilman D, Balzer C, Hill J, Befort B L. Global food demand and the sustainable intensification of agriculture. Proceedings of the National Academy of Sciences of the United States of America, 2011, 108(50): 20260-20264

17. Garnett T, Godfray C J. Sustainable intensification in agriculture. Navigating a course through competing food system priorities. Food Climate Research Network and the Oxford Martin Programme on the Future of Food. Oxford: University of Oxford, 2012

18. Garnett T, Appleby M C, Balmford A, Bateman I J, Benton T G, Bloomer P, Burlingame B, Dawkins M, Dolan L, Fraser D, Herrero M, Hoffmann I, Smith P, Thornton P K, Toulmin C, Vermeulen S J, Godfray H C J. Sustainable intensification in agriculture: premises and policies. Science, 2013, 341(6141): 33-34

19. The UK Government Office for Science. Foresight: The Future of Food and Farming. Final Project Report. London: The Government Office for Science, 2011

20. International Maize and Wheat Improvement Center (CIMMYT). Drought Tolerant Maize for Africa (DTMA). Available at CIMMYT website on May 27, 2020

21. International Crop Research Institute for the Semi-arid Tropics (ICRISAT). Fertilizer Microdosing. Boosting Production in Unproductive Lands. Available at ICRISAT website on May 27, 2020

22. Mohammed Wazed S, Hughes B R, O’Connor D, Kaiser Calautit J. A review of sustainable solar irrigation systems for sub-Saharan Africa. Renewable \& Sustainable Energy Reviews, 2018, 81(Part 1): 1206-1225

23. Bryan E, Ringler C, Okoba B, Koo J, Herrero M, Silvestri S. Can agricultural support climate change adaptation, greenhouse gas mitigation and rural livelihoods? Insights from Kenya. Climatic Change, 2013, 118(2): 151-165

24. Bouis H E, Saltzman A. Improving nutrition through biofortification: a review of evidence from HarvestPlus, 2003 through 2016. Global Food Security, 2017, 12: 49-58

25. Webb P; World Economic Forum. Innovation with a purpose: the role of technology innovation in accelerating food systems transformation. ResearchGate, 2018

26. Reardon T, Chen K Z, Minten B, Adriano L, Dao T A, Wang J, Gupta S D. The quiet revolution in Asia's rice value chains. Annals of the New York Academy of Sciences, 2014, 1331(1): 106-118 